\section{Spain and the}

Doctors: Historical

Theories as

\section{Diagnoses in \\ National}

\section{Psychopathology}

\section{Juan Luis Fernández Vega [*]}

[*] PhD History at Universidad de Cantabria, Santander, España. Graduate in Philosophy (UNED). Graduate in Information Sciences (Universidad Complutense de Madrid). Former professor of historiography at UC. julufernandez@gmail.com.

ORCID: 0000-0001-9197-2283

\begin{abstract}
There has been among historians, philosophers, and semioticians a growing awareness of the theoretical strata involved in the writing of history. Within historical narratives we can find at least three major levels of theory: (i) the naming of events according to everyday concepts; (ii) the interpretation of the class of plot best fitted to the web of events to be narrated; and (iii) the implicit or explicit formal framework employed for systematic narrative. Like medical diagnosis, history applies general knowledge to singular situations; like history, medicine describes events, creates storylines, and draws on general models. This likeness is politically relevant when history is taken as another, higher kind of diagnosis: that of a national malaise in need of political cure. As an empirical case, we analyze a number of historical theories formulated as historical diagnoses in traumatic twentieth-century Spain, and then test the link between theories and therapies.
\end{abstract}

Keywords: Historical theories; Historical narratives; Spanish nationalism.

\section{Espanha e os médicos: teorias históricas como diagnósticos em psicopatologia nacional}

Resumo: Houve entre historiadores, filósofos e semioticistas uma crescente consciência dos estratos teóricos envolvidos na escrita da história. Dentro de narrativas históricas, podemos encontrar pelo menos três níveis principais de teoria: (i) a nomeação de eventos de acordo com conceitos cotidianos; (ii) a interpretação da classe de enredo melhor ajustada à rede de eventos a serem narrados; e (iii) a estrutura formal implícita ou explícita empregada para a narrativa sistemática. Como o diagnóstico médico, a história aplica o conhecimento geral a situações singulares; como a história, a medicina descreve eventos, cria enredos e baseia-se em modelos gerais. Essa semelhança é politicamente relevante quando a história é tomada como um outro tipo de diagnóstico mais elevado: o de um mal-estar nacional que necessita de cura política. Como caso empírico, analisamos várias teorias históricas formuladas como diagnósticos históricos na Espanha traumática do século XX e testamos a ligação entre teorias e terapias.

Palavras-chave: Teorias históricas; Narrativas históricas; Nacionalismo espanhol. 
The discussion whether history is an art or a science seems futile: it is like medical diagnosis.

Lewis Namier, 1952

\section{Historical Narratives as "Theoristories", the Medical Metaphor, and the Spanish Malaise}

T here has been among historians, philosophers, and semioticians a growing awareness of the theoretical strata involved in the writing of history, thus recognizing that historical narratives are a kind of theories about what happened in an irretrievable past. Drawing on German and Italian historicistic traditions, but also on Anglo-Saxon idealism and analytical philosophies of history, it has been noted that in historical narratives we can find at least three major levels of theory: (i) in the naming of events according to everyday concepts or specialized historical dictionaries; (ii) in the interpretation of the class of plot best fitted to the web of events to be narrated; and (iii) in the implicit or explicit formal framework employed for systematic narrative. Naming, emplotment, and formal modelling are thus the main layers in the theoretical constitution of historical narratives. ${ }^{1}$

It might be said that narrative concepts type (ii) are truly characteristic of historical knowledge, insofar they define the grand picture of time, identifying a particular plot-structure with its anthropological and political presuppositions from level (iii). Scientificity of history is often linked to the very possibility of connecting these two realms: the sequential (narrative) and the consequential (deductive) courses of reasoning. Our standpoint contends that every narrative claiming to be true involves this third theoretical level, but that this fact is often obscured because many histories only vaguely refer their events to a broader sociological theory. Plot patterns are like "decline and fall" o "from rags to riches", for example. The American historian Dale H. Porter noted that the kinds of stories that literary critics had classified fitted very well to the kind of histories that historians write (Porter, 1981, pp. 150-157).

As to the third theoretical level, there are mainly two categories: the dynamic and the static. Dynamic theories are theories of, broadly speaking, "evolution". Philosophies of history of the material kind, from Saint Augustine to Edmund Husserl, are examples of this,

1 Fernández, 2018, pp. 95-100. For the understanding of histories as complex pictures, see Ankersmit, 2012. On theories and narratives, see Koselleck, 2001; Fulbrook, 2008; and Rüsen, 2017. 
but also more precise sociological theories such as those of Auguste Comte, Karl Marx, Max Weber, and many others. They identify "stages" of evolution and a certain mechanism for rendering account of historical change. We will see how some neo-Darwinian sociology influenced Spanish historical theories. The "Whig" theory about a steady progress of liberty in modern history also belongs to this epistemic category. But we must be careful: these dynamic theories could be just sublimated narrative patterns of the type (ii). The key is the "mechanism of change", about which there is no current consensus. ${ }^{2}$ On the other hand, we have sociological, anthropological, and economic theories of the static family: underlying each narrative pattern there is an implicit theory on how human beings and society act. As Weber said, even though the historian speaks the "language of life", the validity of his/her narrative depends upon the conceptual scaffolding that permits to explain and to understand historical events (Weber, 1949, p. 94).

Therefore, analyzing some interesting empirical case could be useful for mapping the land of "theoristories", which present this mix of narrative pattern and abstract model, superimposed upon an elementary level made of commonsensical concepts. We have chosen, as a case study, a selection of historical interpretations held in twentieth-century Spain about the traumatic evolution of the country, especially between 1898 and 1978. Since the last quarter of the nineteenth century, Spain felt an acute sense of decadence, stagnation, and collective illness, symbolized by the humiliating defeat in 1898 at the hands of the United States of America, and by the loss of the last remains of the former world empire. "Regeneration", a metaphor of biomedical inspiration, was then the catchword for those promoting the return to a stronger Spain. It had to be the real foundation of a modern, if belated, nationality. ${ }^{3}$ However, the Civil War 1936-1939 and forty years of dictatorship frustrated many hopes. After the establishment of a democratic Constitution in 1978, self-esteem was somehow recovered. But historical theories and public discourses about national malaises are nowadays just experiencing a revival, after the eruption of a strong Catalan push for secession.

Furthermore, we want to explore the link between history and political science through the analogy between historians and physicians. History as a "diagnosis" leading to a "therapy" goes beyond a theoretical interpretation of events in order to weave a text: it plays also on the powerful analogy between politics and medicine, sometimes rooted in the

\footnotetext{
${ }^{2}$ On the role of evolutionist assumptions in an outstanding sample of contemporary historiography, see Fernández, 2017. On the liberal historical theory, see Butterfield, 1931.

${ }^{3}$ A fresh overview in Álvarez Junco \& Fuente Monge, 2017, pp. 321-342. Also, Fox, 1998; García Rovira y Riquer i Permanyer, 1999; García Cárcel, 2004. A classical survey was Laín Entralgo, 1949. Compare with the German feeling of national belatedness in Plessner, 2001. From the point of view of nation-building through pictorial narratives, see Pérez Vejo, 2015.
} 
metaphorical identity between human body and polity, as in Thomas Hobbes's De Corpore Politico (1640).

Although the political usefulness of history had its locus classicus in Thucydides (1998, I.22.4), the remotest explicit tradition of the salutary triangle formed by history, politics, and medicine is to be found in Polybius of Megalopolis. Having highlighted that bare narrative is not enough, because the cognitive and practical utility of history requires that it should explain the causes of events, he established a thorough parallelism between, on the one hand, theory of diseases (logiké iatriké), dietetics (diaitetiké), and surgery and pharmaceutics (cheirourgiké kaí pharmakeutiké), and, on the other hand, study of written documents and arrangement of contents, acquaintance with topography, and mastery in political affairs (Polybius, 1966, XII, 25d-25e). Firsthand knowledge was something that historians, physicians, and politicians must have in common. It might be noted that, in Polybius, there is already a feedback circuit between history and (the "medical" role of) politics: you must be a political mind in order to write sound history, but as you gain historical knowledge your political mind improves too. There is a reciprocal enlightenment of history and politics, under the spell of medicine, and this triangle will survive throughout the centuries.

A meaningful moment of this continuity, related even to Spain as an empirical proof, was Leopold von Ranke's 1836 inaugural address in Berlin: "De historiae et politices cognatione atque discrimine" ("On the affinity and the difference between history and politics"). The German father of modern historical scholarship contended that, due to the relevance of traditions in the genesis of the particular nature of each state, whoever wishes to rule over one of them should have a sufficient knowledge of its history. Even considering politics as just an economic-administrative science, "no less necessary to the republic than medical discipline to the human body", and admitting that "human society has, as it were, its own body" (Habet enim societas humana et ipsa suum quasi corpus), historians still would have something to say. Firstly: many events that they study come from the "conditions of health" of the states (Gesundheitszustande des Staates). Secondly, and more important in Ranke's opinion: just as a "strong and healthy man" does not direct his life just through medical prescriptions, the healthy state does not act only according to the leges naturales civitatum in order to fulfill economic-administrative duties, but above all in order to achieve higher goals, suggested by its spiritual forces, after reflection on its own history. State health went, for Ranke, beyond mere administration: it was the accomplishment of a "mission" signaled by destiny (or providence, as he believed). ${ }^{4}$ On the contrary, wherever statesmen want to impose a global archetype disregarding the historical structures of a society, the ruin will come. Ranke offered the example of Spanish liberals, immersed since 1833 in a bloody civil war

${ }^{4}$ Ranke, 1872, p. 276 (Latin text), p. 290 (German text). In English, our translations. 
against traditionalists. Spain showed the unhealthy consequences of imposing an abstract modern policy against the historical pillars of a country. ${ }^{5}$

In the twentieth century, we encounter again the history-medicine topos neatly stated by a great British historian, Lewis Namier, but this time as an epistemological reflection. For him, the analogy made full sense as regards to method: "The discussion whether history is an art or a science seems futile: it is like medical diagnosis; a great deal of previous experience and knowledge, and the scientific approach of the trained mind, are required, yet the final conclusions (to be re-examined in the light of evidence) are intuitive: an art" (Namier, 1952).

Thus, the general basis for our case-study has been set up. The relationship between history and medicine is mediated by political knowledge, which in turn is fed by contents about past events and by theses on the nature of society. Taken as a social physician, the politician needs historical orientation (Ranke). But historians themselves need two parallel epistemic virtues: that of firsthand knowledge (Polybius), and that of a fine adaptation of theory to practice (Namier, 1952, quoted from Stern, 1973, pp. 372-381). While politics seems to have the upper hand in the prescription of future therapies, historical theory (that is, the interpretations of the overall pattern, and of general causes) is responsible for a diagnosis of the political situation, not only insofar the latter has been generated by past events, but also insofar the historian has a sort of medical tact.

In twentieth-century Spain, the historical interpretations that we will survey presented themselves explicitly as diagnoses of a national malaise in search of a political cure. "An essay in pathology of the Spanish soul" was in 1921 one of the outstanding texts in Luis Araquistáin's book Spain in the crucible. That very year, José Ortega y Gasset published what would become one of his most renowned historical essays, Invertebrate Spain. Later on, scholar and diplomat Salvador de Madariaga would publish an essay in collective psychology, and a full interpretation of Spanish history drawing freely on the Völkerpsychologie that was mainstream in the first half of the century, as shown also in Rafael Altamira, the great renovator of the general history of Spain in a national-liberal élan (Altamira, 1917). National psychology led naturally to national psychopathology when the nation was in trouble.

The malaise of Spain was diagnosed as a persistent deviation from the West-European standard of national-liberal state and scientific progress; this deviation was attributed to a number of vices or failures in the national soul and customs. The malaise of abnormality was considered a result of an abnormal historical path, because of the soul of the traveler or of the wrong path itself. In some cases, a negative opinion about the tragedies of Europe in the twentieth century led to the defense of a renewal within the Spanish tradition,

${ }^{5}$ Ranke, 1872, p. 278 (Latin), p. 292 (German). 
instead of the usual program of "Europeanization"; Spain would be now the savior of a sick Europe.

We will analyze the theories of Spanish history defended by five outstanding academic historians (Rafael Altamira, Ramón Menéndez Pidal, Américo Castro, Claudio Sánchez-Albornoz, Jaume Vicens Vives) and four renowned historical essayists and philosophers (José Ortega y Gasset, Luis Araquistáin, Salvador de Madariaga, María Zambrano). Their visions were, and still are, deeply influential both within Spain and abroad. The list could be expanded at will in an encyclopedic fashion, but for our purpose this sample will suffice. ${ }^{6}$ The selected writers were arguably among the greatest Spanish interpreters, between 1898 and 1978, of Spanish past. ${ }^{7}$

Most of them had not only theoretical foundations, but also firsthand political experience that would enrich their Namierian "intuitive art": they would die in permanent exile after the Civil War 1936-1939, or would return under censorship in postwar times, or very old-aged at the return of democracy, or would suffer in Francoist Spain an official hostility. Most of them, as well, were at some point ministers of the Spanish Government, ambassadors, members of parliaments, or academic authorities. Eventually, most of them lectured in foreign universities such as Oxford, Princeton, Columbia, and a host of other European and American higher education centers. Besides, all of them were, at least until 1977, political losers. As Reinhart Koselleck once noted, there is a strong link between historical defeat and historical analysis (Koselleck, 2001, p. 92). Pain leads to clairvoyance, joy is historically blindfolded. So, historiography could be taken as the cognitive therapy for political frustration. But frustration is rather abundant in a country with titles such as "The nation that does not exist", "The inexistent nation" or, straightforward, "History of a frustration", to mention just three recent samples (Duque, 2014; Quiñonero, 2017; Colomer, 2018).

\section{Historical Psychopathology in Spanish Historians}

Our survey starts with the reaction of Rafael Altamira shortly after the "disaster" of 1898. The reader will realize that, apart from divergences in historical theory, all these thinkers coincided in a rather liberal state of mind; we may safely see them as Spanish variants of

\footnotetext{
${ }^{6}$ All translations into English from texts published in Spanish are ours.

7 Other bright thinkers, such as Pedro Laín Entralgo, Julián Marías, and Gustavo Bueno would deserve careful attention in a broader, monographic study, along with a host of contemporary Spanish (and British and French) academic historians, such as Pere Bosch-Gimpera or even the erudite amateur Salvador Carretero Jiménez.
} 
what Herbert Butterfield called "the Whig interpretation of history" (Butterfield, 1931). The healthy narrative pattern was supposed to be that of the leading Western countries.

In Psychology of Spanish People (1902), Altamira, the creator of the first truly scientific general history of Spain, a historian formed with the best historiographical positivism in Paris, tried to give some patriotic hopes to a demoralized nation. For Altamira, objective history and national education would cure Spaniards from false images about their past and their possibilities, which produced a lack of self-awareness and self-assurance. The book, inspired by Fichte's Addresses to the German nation, intended to face the two main enemies of the Spanish self-reliance: pessimism induced from failures and from foreign "hispanophobia"; and "the lack of national unity as shown in the disputes about the concept of country" (patria) (Altamira, 1917, p. 12). Through the exhibition of past examples of ability, it would be demonstrated the fitness of Spain for civilized tasks. Through national education, common feelings of belonging would be reinforced. Altamira's historical diagnosis was stated as follows:

The complicated gear of political compromises that the inheritance of the Aragonese-Catalan and Austrian house threw on our shoulders at the beginning of the Modern Age, and those that later brought us with Philip V the Bourbon and Italian connections, did not allow us to fulfill normally the evolution that began throughout Europe, transforming the medieval civilization in relation to the organization and orientation of social forces. By attending to the outside, we had to neglect the interior, which did not appeal to us as much as the outside, that is, as our international power (except for the interregnum of the eighteenth-century reformist period); and the persistent iniquity and bad faith of all $\mathrm{Eu}$ rope, which feared to see us resuscitate even after death, finished the work. Truth is that our kings did nothing to gain sympathy, destroying rather possible friendships or exacerbating hatred with the religious policy of intransigence, during the House of Austria; aside the errors of international politics in other matters. All these facts incline me to believe, today, that a large part of the causes of our rapid fall should be placed in the interposition of obstacles that dispersed our forces and did not allow them to concentrate on the critical point to resolve the internal crisis. (Altamira, 1917, pp. 155-156, our italics)

This has been ever since the national-liberal interpretation par excellence. We may read in this long quotation a narrative pattern of the second theoretical level: an initial development is interrupted and deviated because of the arrival of a foreign dynasty, the Habsburgs; this deviation occurs again with the Bourbon kings; this way, the inner development was unable to overcome external difficulties, and was deflected from the "normal" road of European evolution. Precisely, the theory about a "normal" evolution is a third-level historical apriorism, in the liberal sense of a historical anthropology of progress rooted in the Enlightenment. But Altamira betrays also the influence of the concept of a spontaneous inner 
national development, so dear to German historicism since the age of Goethe and Herder. ${ }^{8}$ Thus, we have a mix of Enlightenment and historicism.

Altamira's thesis is being nowadays reshuffled in Spanish historical science as the negative influence of the imperial enterprise upon the unfinished formation of the Spanish nation (Bernal, 2005). For Altamira, history showed that Spain was apt for a "re-flowering", "on the basis of natural conditions demonstrated in past times". Thus, against the fatalism of a constitutive disability, the historian recommended as a therapy (remedio) neither Macías Picavea's technocratic dictatorship nor Joaquín Costa's "iron surgeon" statesman, but the "restoration of the credit of our history", yet avoiding "archaeological recession" while adopting a "reform in the direction of modern civilization" (Altamira, 1917, pp. 205-211).

The researcher who established the next academic canon in Spanish general history was Ramón Menéndez Pidal, whose monumental collective work stretched far beyond his death, in a series of publications beginning in 1935 and concluding in 2004, with 65 volumes and more than 400 authors. In his prologue from 1947 to the volume on the pre-Roman origins of Spain, Pidal wrote a global essay about its national trajectory: The Spaniards in history: ups and downs in the curve of their political life. He found out as a permanent feature the individualism of the inhabitants and their "secluding character", with a difficult cooperation between elites, and an overall sobriety of life. Thus, the Spanish curve offered "very distanced summits", "very long waves", a "bass sound that is heard less than that of other great peoples". The solution would be the meeting of the two Spains, the conservative and the progressive, in the field of a common tradition; through a fairer, non-partisan, selection of elites, "they will shorten the depressions and interruptions in the historical curve". Pidal reproached the leftists for having abandoned the riches of Spanish tradition, conceding to right-wingers the exclusive use of its cultural meaning.

One aspect of this "secluding character" was the regionalist tension. Pidal protested against the "disintegrating voluptuousness" represented by nationalistic areas such as Catalonia and the Basque Country, although he also criticized the practical shortcomings and lack of local tact of the unitary state. Nowhere it is to be found how Pidal could hope to overcome Spanish individualism by a sudden and mysterious desire for coordination, but his diagnosis (an innate tendency to dissociation) and therapy (a change to cooperation under a shared sense of tradition) were altogether clear (Dardé, 2006; see also Dardé, 1999). In his case, an eternal ethnic psyche provides the general framework for a sad narrative pattern made of rare great achievements and long periods of stagnation and decay.

A year later, the exiled Republican philologist Américo Castro, born in Brazil, was producing in Princeton a revolutionary interpretation of Spanish history (and malaise, as it

${ }^{8}$ See for example, Iggers, 1988. 
could be expected after a bloody civil war) (Castro, 1996). Against an eternal Spanish type formed in Prehistory or at least in pre-Roman times, Castro defended the medieval constitution of the "Spaniards", in the complex coexistence between the Christian population and the two Semitic cultures established on the Iberian Peninsula: Muslims and Jews. This coexistence had aspects of spiritual influence but also of lethal struggle. For Castro, the main consequences of these long years of "Reconquista" were two: (i) the assimilation of a fanatic view of religion, taking the apostle Saint James (Santiago) as a Christian Muhammad and creating an atmosphere of ever increased repeal of tolerance; (ii) the forced incorporation of converted or neo-Christians (conversos), and the establishment of the Inquisition for controlling that relapsed Jews or unfaithful Muslims would not control Spanish Catholic society and state; or granting that they would be expelled from the country if they resisted baptism. From these traumatic processes Castro deduced many sociocultural characteristics and events in Spanish history since the fifteenth century, including the Civil War 1936-1939, an exercise in political-religious fanaticism. ${ }^{9}$

Castro saw that the "strange manner" of Spanish history, so different from other European countries, needed to be "examined rather forgetting the ideas of material progress and decadence, of political might and technical efficiency" (Castro, 1996, p. 23). Just as we will see in Zambrano, Castro finds in Spanish historical tradition the highest values of culture: painters such as El Greco, Velázquez, or Goya; writers such as Cervantes, Góngora, Lope de Vega; in his own time, the scientist Santiago Ramón y Cajal, the poets Antonio Machado and Federico García Lorca, the philosopher Ortega y Gasset, the musicians Isaac Albéniz and Manuel de Falla. Castro would not accept the death or sterility of Spanish culture, even acknowledging material backwardness or inability to consolidate a modern state. For him, since the seventeenth century "the disintegration of the collective will is patent". The political myth of a universal Catholic empire had lost efficiency. The collective will would never come back: there will be different and opposed projects.

Castro declared himself astonished before the great deal of thinkers who had tried "to explain the existence of Spain as a chronic disease". Such standpoints were really "a form of their Hispanism", the way of living in yearning (vivir desviviéndose) (Castro, 1996, pp. 4546). It was the concrete structure of national formation during the Middle Ages what rendered account of Spanish cultural features and lifestyles: unity in belief, lack or prosecution of thought, incapability for doing things, disdain for mechanical work, quietism, craving for eternity and glory, individualism, separatism, and so on. ${ }^{10}$ The cure for Spaniards was a better awareness of the origins of their cultural shortcomings, but also a better appreciation

9 See a critical survey in Álvarez Junco; Fuente Monge, 2017, pp. 375-376.

10 See a complete reference of qualities in Castro, 1996, pp. 656-657. 
of the great political and spiritual deeds reached in the periods of Spanish zenith. "My historiography", Castro writes in 1970, "aspires to be explanatory and not for demolishing. It tends to use the exam of the past and the observation of the pleasant and the atrocious, leaving aside sects and partisanships, in order to extract of it all vaccines that immunize against fratricide (cainismo) and self-destruction" (Castro, 2000, p. 89).

Therefore, Castro's general framework is a repressed psyche historically constructed about the threshold of modernity; the narrative pattern, a steady and pathological deviation from the Western main road, but also from the best Spanish culture. Spain put aside even her own virtues. The therapy is to recover them through historiography.

Another exiled Republican, the medievalist Claudio Sánchez-Albornoz, reacted energetically against Castro's theses, opening up what became the great controversy about the meaning of the historical genesis of Spain. In Spain, a historical enigma (1957) Albornoz offered a very different theory, more rooted in ancient and permanent features of Hispanic peoples (a temperamental heritage influenced by geography), whose reaction during eight centuries to the Muslim conquest determined the structure of mentality, which was put at work when the Renaissance gave way to the building of an empire in Europe and overseas. ${ }^{\text {Il }}$ For him, the formation of Spain's unity had been interrupted by the sudden integration of the joint Castile-Aragon polity into the Habsburg empire. The complicated problems that Austrian kings had to face "blinded them to the most decisive of all, (...) the making of Spain" (Sánchez-Albornoz, 1975, p. 1039). The "short circuit" of modernity, by substituting heretics for Muslims, prevented the transformation of the medieval heritage (warring tendencies, religious adherence). Later on, two Spains will react very differently to European ideas: adopting them in modernizers, or rejecting them in traditionalists. Albornoz hoped that the two Spains and their cycle of civil wars would be overcome through the reckoning of their shared temperament and way of being (Sánchez-Albornoz, 1975, p. 1208).

But Spain was a monumental work not easily available to the average Spaniard of the time, and the historian wrote in 1979 an abridgement so as to denounce more effectively Castro's mistakes: "I believe that, in spite of the centuries and centuries of battle against adversity, we can straighten out the faults produced in our psyche and our operative power by our cruel and terrible clashes with the historical tides that have come our way. However, in order to cure our ailments, it is important that they be rigorously diagnosed" (Sánchez-Albornoz, 1979, p. 18).

Just because Castro's diagnosis was wrong, his therapy would be useless or even harmful ("poisonous"). Spain had superseded, if belatedly, three European revolutionary waves: religious, political, and social. Thus, "we can look to the future without too much anguish",

"The basic thesis in Sánchez-Albornoz, 1975. 
and recall the "marvelous fruits" presented to the world (Sánchez-Albornoz, 1979, pp. 99100). Sánchez-Albornoz general framework is, thus, both ethnic psychology and the conventional commonsensical framework for political, diplomatic, and cultural behavior. His narrative pattern recalls that of Altamira as the tale of an inner modernizing development suddenly interrupted from abroad, and handicapped by the permanence a long medieval ideological heritage, which explains the recurrence of civil wars.

We may now take as a final step in the field of academic historians the vision that Jaume Vicens Vives, a Catalan scholar, expressed about the global development of Spain. In his Approach to the History of Spain, published in 1954 and reformulated in 1960 (the year of his death in Lyon), he, abandoning essentialist conceptions of the country, put the focus, following the path of the Castro-Albornoz controversy, on central issues: on the one hand, "the imperfection of Spain for following the course of the Western civilization towards capitalism, liberalism, and rationalism"; on the other, "the failure of Castile in its mission for making of Spain a harmonious commonwealth, self-satisfied and acquiescent" (Vicens Vives, 2003, p. 12). Castile had failed because of its spiritual misunderstanding of the capitalistic world, while her ambitious foreign policy was unsustainable without a sound economy (Vicens Vives, 2003, pp. 108-110). The imperfection of Spain can be seen in many aspects as derived from the dynastic entanglements experienced from Charles I to Charles II, and from the conquest of America: loss of men and energies.

In his diverse writings on contemporary Spain, Vicens highlights the crisis of the twentieth century as provoked by European and domestic causes alike. Among the latter, (i) the sense of disquietude in Castilian pessimism around 1898 and Catalan optimism about 1902; (ii) the dissent between Castile and Catalonia about the best organization of the Spanish state; (iii) the fight between political Catholicism and anticlericalism; (iv) a turbulent anarchism against an excessively conservative policy of the ruling classes; and (v) the agrarian issue, similar to that of Eastern Europe. The other causes are plainly European (freedom vs authority; private vs collective; humanism vs materialism). But "Spanish temperament" and the magnitude of problems brought about "an extreme violence" (Vicens Vives, 2003, pp. 150-154).

Decisive in contemporary Spain had been the triple influence of, and reaction to liberalism, industrialism, and Romanticism. Spaniards received these European impulses in a country mostly agrarian and poor, dominated by Catholicism and by the memory of past imperial glories (Vicens Vives, 2011). Vives notes the continuous interference of European developments in Spanish historical turns. He even blames totalitarian Europe of inducing the Civil War in 1936. Thus, even though he accepts a Hispanic temper of mind, and some features rooted in medieval history, such as religion and regional diversity, Vicens Vives prefers to explain Spanish contemporary history from contemporary historical causes, some 
of them continental, some others exclusively Spanish. He hoped that Spain could overcome the division established since 1808 between modernization and tradition, and that the second half of the twentieth century would set the economic and educational basis for a Spanish success (Vicens Vives, 2011, p. 246).

In Vicens, therefore, the general framework is formed by the great "-isms" that had constituted modern Western Europe, but also a quasi-eternal "temper" prone to violence. The concrete path is of deviation regarding the "isms", and, in the case of the formation of the national state, the story of a parallel failure of the Castilian hegemony and the Catalan alternative. It is a complex pattern of multiple antitheses, which coalesce in each civil war, notably in 1936-1939.

\section{Historical Psychopathology in Spanish Philosophers and Essayists}

Within Spain or in exile, some historical interpretations of widespread influence were penned not by academic historians, but by talented philosophers, essayists and writers. Almost a century later, they still are read, studied, commented and quoted in Spanish public life. Perhaps just a few would quote nowadays Altamira or Menéndez Pidal, but Ortega y Gasset is cited almost on a daily basis in general press, scholarly articles, and books.

In his seismic essay from 1921 about the invertebrateness of Spain (a biological diagnosis in itself), Ortega thought of three layers of historical structures that explained the "Spanish disease" (enfermedad española) (Ortega, 2012, p. 480), acutely felt about the years of the First World War as decadence and disintegration. The ultima ratio was to be popular "aristophobia": "After having looked at and carefully reviewed the diagnoses that are usually made of the deadly disease suffered by our people, I seem to find the closest to the truth in aristophobia or hatred for the best" (Ortega, 2012, p. 493, our italics).

At first, Ortega identifies a surface layer of sickness: political abuses and mistakes; defects in government; religious fanaticism; lack of education. They are mainly "symptoms", but from the historical perspective one should not give them a great meaning regarding the "national pathology". Secondly, the philosopher observes the "phenomena of disaggregation" patent down the centuries and that have reduced Spain to the peninsular territory, and to a situation defined by "particularism" and "direct action", that is, regional and social isolationism leading to unsupportive strategies. This was for Ortega "truly a very serious disease of the Spanish body", yet again more a result than a cause.

The cause is more radical and is to be discovered in "the very soul of our people". Spanish problems are not the effect of accidental catastrophes of external origin, but consequences of "intimate defects", basically a "perversion of social instincts" in need of urgent cure: "The 
sentimental rebellion of the masses, the hatred of the best, the scarcity of these: this is the real root of the great Hispanic failure" (Ortega, 2012, p. 509). Ortega links these collective sentiments to the frailty of the Visigoths, the weak Germanic people that first unified Spain and then lost her to the Muslim invaders (while the strong Franks had created the basis of France and the aristocratic feudalism). The Spanish ascent in the Renaissance was more apparent than real, a formal fruit of a sudden political unification. Yet from the XVII century onwards, the "Tibetanization" of Spain makes of her a deviated path, compared to the evolution of Europe. This is the main narrative pattern that corresponds in level (ii) to the "aristophobia" predicated in level (iii).

As masses are deaf to intellectual warnings, they must fail completely "in order to learn though their own lacerated flesh what they refuse to hear". This apocalyptic tone in Ortega will be dramatically confirmed fifteen years later in the Civil War. Ortega's alternative therapy was the call to a change of sea: "If Spain wants to resuscitate it is necessary that a formidable hunger for all perfections takes over her"; the new direction had to be the "imperative of selection", so as to create "a new type of Spanish man" (Ortega, 2012, p. 511).

Luis Araquistáin, a Basque-Cantabrian journalist inclined from liberalism to socialism, was a brilliant, polyglot, autodidact sociopolitical thinker. One should note in passing that, if "Europe" was before 1914 the watchword for Spanish modernizers, after the carnage of the Great War attention partially shifted to new models of civilization: the capitalistic United States of America and the communist Soviet Russia; later on, also to the fascist standard in Italy, a country closely connected to Spanish history and culture (in fact, dictatorship in Spain followed the Italian example in 1923 within only eleven months of delay).

Spain in the crucible collected some of his most relevant essays of diagnosis of the Spanish malaise. Medical and biological metaphors were core interpretations in Araquistáin, because he believed that the human body is the model for human societies (Araquistáin, 1921, p. 70). Spain was "a sick body" in which "the parts of vital tendency fight against the parts of mortal one". Every partial crisis just belonged to a national "morbid process". This sickness of Spain came from afar in time, and was expressed in her inability to dispose of her historical waste (residuos sobrantes) to get on with a normal evolutive path. For him, Spanish politics "has been opposed to all social evolution, not only to which we could call biological or spontaneous (...), but also to the mental or reflected, formed in the example and noble imitation of advanced peoples". Therefore, the country had been piling up "explosive substances" such as hunger, discontent, injustice, oppression, arbitrariness, and ineptitude (Araquistáin, 1921, p. 76).

War or revolution would be traumatic means of cure for this deficit of Westernization, but Araquistáin then favored, like Ortega, a deep reform of national "character" through 
"education" in the broadest sense: a better schooling, but also the non-plutocratic newspaper press, and a conscientious political behavior. Only the difficulties of this peaceful evolution and his experience as ambassador to early Nazi Germany will push Araquistáin towards a revolutionary option, as philosophical adviser of the leftist leader of the PSOE, Francisco Largo Caballero.

Yet in the 1920s Araquistáin dismissed merely economic solutions ("job and bread"), educational, or political ("freedom"): all those "remedies" would not touch "the substance of the Spanish problem". "The Spanish radical malaise is not hunger, nor ignorance, nor despotism. All these are just accidental diseases; consequences, not causes, of the original malaise: 'the moral decadence of the Spanish human type"'. What Spain needed was "a moral or behavioral reform" (Araquistáin, 1921, pp. 233-234), translated practically into a "Spanish pedagogy" (Araquistáin, 1921, p. 256).

After the Civil War, the exiled Araquistain wrote the essay Spain before the sociological theory of the state (1953), inspired by the reading of the Austrian social-Darwinist Ludwig Gumplowicz's Die soziologische Idee der Staat (1902). ${ }^{12}$ In short, he applied the theory that explained history as a racial dialectics between conquest, dominion, and assimilation. For him, "the Spaniards are the last colony of the Spanish state" (Araquistáin, 1962, p. 134), because Spain had ever been "either colony or empire" (Araquistáin, 1962, p. 131), but never an integrated whole. Unlike other states, Spanish power never added to violence the virtues of "diplomacy", "compromise" or "consensus". Spain was first a colony of the Habsburg dynasty and then of the Bourbon family. The short experiment of the Second Republic witnessed the return of the conqueror state: "This is the essential history of our country, always identical to itself. We are now just like twelve centuries ago. Because, what do we care if the conqueror is called Muza, Charles V, Philip V, or Franco?" (Araquistáin, 1962, p. 135).

"As you see", he continued, "the diagnosis is devastating and the prognosis must also be serious". Would history teach us that Spain is incapable of improvement? Araquistain asserts that the backwardness of the Spanish state has natural causes, which could be overcome through "the industry of man", and historical causes that could be superseded, leaving behind definitively the "military state" or the "theocratic-military" state born, under Arab influence, from the medieval Reconquista against the Moors and prolonged throughout centuries up to the Francoist dictatorship (Araquistáin, 1962, p. 137). As a solution of Realpolitik, he defended every contribution to the "disintegration of the State of force" in Spain, helping her citizens from outside and favoring the integration of the Francoist state in the international life, for suppressing the legitimation of the regimen as a shield against foreign enemies.

2 The text was later included as Part II in posthumous Araquistáin, 1962. 
Thus, the theoretical models in Araquistáin were first the metaphor of the functional body, and a malaise of national psyche as compared to the standard Western health; and secondly, Gumplowicz's neo-evolutionist theory on conquest and assimilation. The narrative pattern is a succession of dramatic empires in which the Spanish people is ever crushed and enslaved.

The Galician Salvador de Madariaga would also live long years in exile. He was a reference for Spain's international image, owing to his diplomatic work, his widely read essays and novels, and his professorship in Oxford. In Englishmen, Frenchmen, Spaniards he tried the usual "essay in comparative psychology" (Madariaga, 1928). For him, the gravity centers of reaction in the national character were "action" in the Englishmen, "thought" in the Frenchmen, and "passion" in the Spaniards. Madariaga notes that, being "character" and "destiny" the two forces that shape history, it had been rather a destiny that Spain should take the lead in the imperial development of European nations. The "religious passion" led to the conquest of Granada, the unity of the kingdoms, and the discovery and colonization of America. But the "dispersive tendencies" of Spaniards, a result of being men of passion ${ }^{13}$, eventually would triumph, and the empire began to die when the Great Armada sent by Philip II against England was defeated. While Spain created an empire out of passion, France created one through an "intellectual vision", and England another from "a growth-impulse" (Madariaga, 1928, p. 175). As regards "home history", the tale looks similar. Spanish history is a permanent tension between unifying powers, such as Castile, and dispersive Iberian trends, while French history is the triumph of the State, and English history has been made by the people (Madariaga, 1928, pp. 179-180).

In Spain: A Modern History (1930), ${ }^{14}$ Madariaga contends that the basis of Spain's trajectory is an "oscillation" between individualism and universalism, which ever makes the national mediation weak: "This oscillation between the two extremes, man and universe, is the rhythm that dominates Spanish history". Hence the constant features of political life: dictatorship and separatism (Madariaga, 1978, p. 29). Hence also the importance of religion as a compensation to the lack of sociability and public compromise of the individual. Madariaga wittily observed that these characteristics had been inherited by the "Disunited States of Hispanic America". But dictatorship and separatism were only "passions", not the "sense" of the Spanish people. For preserving its qualities, good sense and realism, it needs a "high passion" capable of overcoming the dispersive trend. In the sixteenth and seventeenth

\footnotetext{
${ }^{13}$ Madariaga, 1928, p. 46: "The individual psychology of the man of passion implies a nature rebellious to the chains of collective life".

14 The book first appeared in English in 1930, published by Ernst Benn in London, and by Charles Scribner's Sons in New York. The next year it was published in Spanish.
} 
centuries, the country experienced a "faith" that, he fears, "maybe it will never know again" (Madariaga, 1978, p. 30). Madariaga saw a booming vitality in Spanish people and affirmed that Spain "weighs and will always weigh more as a people than as a nation, and as a nation more than as a state"; her fate would depend from the evolution of universal ideas. He quoted Keyserling as saying that "the highest meaning of Spain for a Europe that likes changes so much is to be the model of essential substance" (Madariaga, 1978, pp. 301-302). The narrative oscillation is a result of a deep and enigmatic passion, possibly originated in the struggle against a harsh environment. Against the background of this kind of anthropology, Madariaga's narrative pattern is a great picture of imperial and spiritual rise and fall, waiting for a second historical chance and a happy ending.

Leaning, like Araquistáin, from liberalism to the left wing of Spanish politics, Andalusian philosopher María Zambrano, a university disciple to Ortega, theorized a very different view on Spanish cultural history as compared to other European nations. In a wartime essay, The intellectuals in the Spanish drama (1937, reprinted in Zambrano, 1998), she valued Spanish traditions and popular spirit well above the philosophical trend hegemonic in the continent since the Renaissance. Some hispanization of Europe was as legitimate a cure as the old Europeanization of Spain.

For Zambrano, the problem was not only decadence, disintegration or backwardness of Spain, but the very outbreak of the Civil War and the risk of imposition of a fascist state alien to Spanish traditions. Spain had separated herself from the European culture when the latter became an idealistic mask. In the idealistic nineteenth century, cultivated people in Spain were nourished by this European philosophy, while the continuators of Spanish culture labored either in serenity, like the novelist Benito Pérez Galdós, or in wrath and resentment, like the polymath Marcelino Menéndez Pelayo. This double cleavage constituted for Zambrano one of the deep causes of the Civil War (Zambrano, 1998, p. 93).

Therefore, for her the sick body was Europe itself. The European disease was "the enmity to life" owing to an adolescent idealism, she wrote in Nietzschean tones. Unable to learn from the terrible experience of the First World War, Europe surrendered to rancor, from which fascism spread as a desperate and criminal idealism of the rhetorical kind. The European projects of humankind, argued the philosopher, had the misfortune of being a mere product of reason, not of feeling (Zambrano, 1998, p. 96). The contribution of the Spanish people to a therapy for Europe lay precisely in a vitalist thinking tending to a true communism.

However, the resolution of the Spanish divide between "vital" and "official" country, between "the heretic Spaniards" or "the good caste", and the "defenders of the country", now traitors supported by fascist powers, had to be found in real fight, in historical violence (Zambrano, 1998, p. 99). "The Spanish people are nowadays assassinated because it has 
intuited their magnificent power for transforming the world" (Zambrano, 1998, p. 121). This way, Zambrano's view of Spanish history blended the spiritual failure of rationalist Europe (a Husserlian coetaneous theme) and the wrong invention of tradition by conservatives within Spain.

In a letter to the physician and essayist Gregorio Marañón, a Republican friend of Ortega's who had, however, rejected the Republican revolutionary drift, Zambrano recognized a profound social split: "A terrible disease nested in Spain and has produced the current catastrophe” (Zambrano, 1998, p. 117), but for her it was an epic fight for dignity against dark forces supported by foreign invaders. In another text, Zambrano censures that traditionalists had created "a past of nightmare" and, as a consequence, a rebellion had surged out of utopian schemes, rejecting all the national past. It was "the terrible fact of not having tradition updated". Yet in the Civil War the people are being liberated of the intellectual and moral disease: "Spain has again history" (Zambrano, 1998, p. 142). During her many years in a difficult exile, Zambrano will abandon the road of political revolution, in favor of a deeper reflection about the philosophic-historical signification of Spanish culture. In these writings, spiritual renewal of national traditions is interpreted as the best mean for humanizing contemporary life.

The history of Spain does not follow that of the remainder of the West: our time is not their time; we go before or after, or before and after -which is tragedy. Spain has not accepted her history. There are so many proofs of that! (...) It happens that Spain is not a nation, but more and less: the seed of a continent, I would say of a way of life being given birth and always being interrupted. (Zambrano, 2002, pp. 124-125)

We may see, in this narrative pattern of an inner development suddenly and repeatedly interrupted, the tragic kind of plot that was shared by historians and essayists. The general framework is an existential anthropology, of vitalist tone like that of her master Ortega, inspired by the vitalist development of philosophy in Germany.

During the Second World War, Zambrano diagnosed the malaise of Europe as a "fatigue" regarding its constitutive Augustinian tension between ideals of resurrection (city of God) and realities of failure, "between the good I want and the evil I do" (Zambrano, 1988, pp. 64-65). In the 1950s, when she tried to put in context Ortega as a Spanish philosopher, Zambrano, without analyzing the full set of "diagnoses" about the Spanish problem, took for granted the fact of "the non-synchronization of Spain with Europe since the seventeenth century". For her, the issue, stated summarily, was that "Spain does not seem to have accepted her history, and that this is the origin, the very root of our illnesses, of the so called 'decadence', and of that destructive process, our civil wars". After the Concilium of Trento, Spain had renounced to her history. A sign of this "fatigue" was the poverty of national 
historiography. "Those who more deeply have been interested in the history of Spain just intended to dissent from it: the reformists", observed Zambrano. Culturally isolated, Spain "had become a sphinx: the sphinx of the West" (Zambrano, 201l, p. 117ss). The vitalist line of philosophy created by Ortega was a true therapy: "This was the remedy that we, Spaniards, needed; our cure and our exorcism: to accept our history, to accept history. Yet this cure is not only for the Spanish man; it is universal, because it is the very human condition" (Zambrano, 2011, p. 123).

At the end of this paper the reader will find a synoptic box of the results of our analysis about these nine Spanish "theoristories". Now we proceed to some conclusions.

\section{A Cure for the Doctor, before a Cure for the Patient}

It might be noted that, in these historical interpretations of Spanish malaise, there are two main strategies. The first one explains the plot of events through permanent features of Spanish people or society. An eternal, anthropologically determined Spain is the cause of the curves in Spanish history, the ups and downs of her narrative pattern. The second strategy highlights, instead, the fateful plot as the very structural cause of the inherited troubles: as Spaniards had to fight for such a long time with Muslims, they needed the stark adherence to Christian religiosity and this, in turn, made them unfit to modern economic and cultural life. But even in this line of narrative it is sometimes searched, as in Araquistáin, an Iberian substratum that finally leads back to anthropology.

The preeminence of the causal power of the collective psyche provides a diagnosis demanding a whole cure of the character. Spain must become another Spain, in cultural terms. On the contrary, once taken historical evolution as the result of a rather catastrophic accumulation of adversities, the remedy for Spain is a sort of reconstitution of her own self. Her task must be resumed and successfully crowned, away from the "black legend" (see Roca Barea; Espada, 2017).

We could thus conclude that the relationship between plots and formal frameworks can present two major systems: histories where the formal framework rules absolutely over the interpretation of facts (here, Spanish history explained by an eternal Spanish character), or histories in which the fateful pattern of the plot is the source of new general structures that, therefore, have something of contingent in the long run, and can be changed. There is essentialism whenever the third level predominates, and occasionalism whenever the second calls the shots.

What is conspicuous in the case of twentieth-century Spain is the coincidence in many authors of the medical metaphors. The very use of this trope revealed the craving for 
political solutions to a state of affairs deemed deplorable. However, illness has as a counterpart the state of good health. Spain's historical diagnoses assumed this healthy situation to be that of the advanced Western nations, especially Great Britain and France, sometimes Germany. "Theoristories" of Spain were full of judgments of value regarding the positive standard that was considered as the "normal" path in civilization: the canonical, Whig, Western plot.

By means of the kind of plot and/or the kind of anthropological knowledge invoked, historical narratives become clinical stories only when the thinker is convinced that the evolution of his/her society is pathological. But, in turn, this question only emerges from political sensitivity and motivation. The use of history as diagnosis is just the oblique expression of a metaphorical identity between politics and medicine. Even though it could also be true that, as Namier argued, history and medicine share the art of applying general knowledge to singular events, this community of structure belongs as well to politics, which Ranke admitted also as an art, not just a science.

Knowledge is the cure for ignorance, that is, for incertitude and fear before the world. Thus, history as knowledge should be the cure against oblivion, ideological manipulation or simply an unmanageable excess of memory. We have surveyed the personal effort of nine historical thinkers who intended to reduce to concepts the dramatic stream of Spanish life. Spanish historical doctors were weaving new "theoristories" for a better understanding of the traumatic present through diagnoses of an ambivalent past. The cure for the country required the previous cure for its poor historical thinking. Hence the political resonance throughout the years of the essays and treaties here examined. 
Box 1 - Summary of historical diagnoses by nine Spanish thinkers, 1898-1978

\begin{tabular}{|c|c|c|c|c|}
\hline AUTHORS & $\begin{array}{c}\text { General } \\
\text { Framework }\end{array}$ & $\begin{array}{c}\text { Plot } \\
\text { Pattern }\end{array}$ & Diagnosis & Therapy \\
\hline $\begin{array}{c}\text { RAFAEL } \\
\text { ALTAMIRA }\end{array}$ & $\begin{array}{l}\text { Standard of } \\
\text { Civilization } \\
\text { (Whig). }\end{array}$ & $\begin{array}{l}\text { Initial development deviated by } \\
\text { dynastic foreign compromises: } \\
\text { dispersion, "hispanophobia". }\end{array}$ & $\begin{array}{l}\text { Pessimism. } \\
\text { National } \\
\text { disunity. }\end{array}$ & $\begin{array}{l}\text { National education in } \\
\text { objective and } \\
\text { positive history. }\end{array}$ \\
\hline $\begin{array}{l}\text { RAMÓN } \\
\text { MENÉNDEZ } \\
\text { PIDAL }\end{array}$ & $\begin{array}{l}\text { National } \\
\text { character: } \\
\text { Individualism. }\end{array}$ & $\begin{array}{l}\text { A pattern of long waves with } \\
\text { very distanced summits. }\end{array}$ & $\begin{array}{l}\text { Lack of } \\
\text { cohesion. }\end{array}$ & $\begin{array}{l}\text { A shared historical } \\
\text { tradition. Non- } \\
\text { partisan selection } \\
\text { of elites. }\end{array}$ \\
\hline $\begin{array}{l}\text { AMÉRICO } \\
\text { CASTRO }\end{array}$ & $\begin{array}{l}\text { National } \\
\text { character of } \\
\text { medieval origin. } \\
\text { Standard of } \\
\text { civilization. }\end{array}$ & $\begin{array}{l}\text { Deviation from Europe owing } \\
\text { to the Reconquista. } \\
\text { Intolerance, traumatic } \\
\text { assimilation. Myth of universal } \\
\text { Catholic empire. Disintegration } \\
\text { of collective will since 1600s. }\end{array}$ & $\begin{array}{l}\text { Fratricidal } \\
\text { tendencies, } \\
\text { self- } \\
\text { destructive } \\
\text { dynamics. }\end{array}$ & $\begin{array}{c}\text { Better understanding } \\
\text { of origins and } \\
\text { valuation of great } \\
\text { deeds. }\end{array}$ \\
\hline $\begin{array}{l}\text { CLÁUDIO } \\
\text { SÁNCHEZ- } \\
\text { ALBORNOZ }\end{array}$ & $\begin{array}{l}\text { National temper } \\
\text { geographically } \\
\text { influenced. } \\
\text { Cycles of external } \\
\text { waves. }\end{array}$ & $\begin{array}{l}\text { Integrative process interrupted } \\
\text { by Habsburgs. Permanence of } \\
\text { medieval traits. Rival reactions } \\
\text { to foreign stimuli. }\end{array}$ & $\begin{array}{l}\text { Inner and } \\
\text { violent division, } \\
\text { exemplified } \\
\text { in civil wars. }\end{array}$ & $\begin{array}{l}\text { Spain needs } \\
\text { reconciliation through } \\
\text { a common ground: a } \\
\text { shared way of life. } \\
\text { Optimism. }\end{array}$ \\
\hline $\begin{array}{l}\text { JAUME } \\
\text { VICENS } \\
\text { VIVES }\end{array}$ & $\begin{array}{l}\text { European } \\
\text { structures. } \\
\text { Standard of } \\
\text { civilization. } \\
\text { "Spanish } \\
\text { temper". }\end{array}$ & $\begin{array}{l}\text { Convergent stories since 1808: } \\
\text { Castilian vs Catalan: } \\
\text { Catholicism vs anticlericalism; } \\
\text { Anarchism vs conservatism; } \\
\text { European anthiteses. }\end{array}$ & $\begin{array}{c}\text { Spain's } \\
\text { failure in } \\
\text { modernizing. } \\
\text { Castile's failure } \\
\text { in harmonizing. }\end{array}$ & $\begin{array}{c}\text { Economic and } \\
\text { educative progress. }\end{array}$ \\
\hline $\begin{array}{l}\text { JOSÉ ORTEGA } \\
\text { Y GASSET }\end{array}$ & $\begin{array}{l}\text { Natural structure } \\
\text { of elites / masses. } \\
\text { Standard of } \\
\text { civilization. }\end{array}$ & $\begin{array}{l}\text { Unified by "weak"' Goths, too } \\
\text { long Reconquest. } \\
\text { Tibetanization since the } 17 \text { th } \\
\text { century, deviation from } \\
\text { European lifestyles. }\end{array}$ & $\begin{array}{l}\text { Aristophobia } \\
\text { and its effects: } \\
\text { separatism, } \\
\text { direct action. }\end{array}$ & $\begin{array}{l}\text { Learming through } \\
\text { catastrophes, or } \\
\text { imperative of } \\
\text { selection. }\end{array}$ \\
\hline $\begin{array}{c}\text { LUIZ } \\
\text { ARAQUISTÁIN }\end{array}$ & $\begin{array}{c}\text { Western } \\
\text { standard. } \\
\text { Metaphor of the } \\
\text { body. } \\
\text { Gumplowicz's } \\
\text { social-Darwinism. }\end{array}$ & $\begin{array}{l}\text { Deviation from Europe for lack } \\
\text { of waste-disposal for outdated } \\
\text { features. } \\
\text { A succession of colonial and } \\
\text { imperial stages since Antiquity. }\end{array}$ & $\begin{array}{l}\text { Moral } \\
\text { decadence } \\
\text { of the } \\
\text { human type. }\end{array}$ & $\begin{array}{l}\text { War \& revolution, or } \\
\text { re-education of } \\
\text { national character. }\end{array}$ \\
\hline $\begin{array}{l}\text { SALVADOR DE } \\
\text { MADARIAGA }\end{array}$ & $\begin{array}{l}\text { National } \\
\text { character: } \\
\text { passion. }\end{array}$ & $\begin{array}{c}\text { Oscillatory periods: unifying } \\
\text { universalism or dispersive } \\
\text { particularism. }\end{array}$ & $\begin{array}{l}\text { Lack of social } \\
\text { equilibrium. }\end{array}$ & $\begin{array}{l}\text { Recovering universal } \\
\text { ideals, counterbalancing } \\
\text { the dispersive tendency. }\end{array}$ \\
\hline $\begin{array}{c}\text { MARÍA } \\
\text { ZAMBRANO }\end{array}$ & $\begin{array}{l}\text { Existential } \\
\text { anthropology. } \\
\text { Idealism or } \\
\text { vitalism. Adding } \\
\text { feeling to reason. }\end{array}$ & $\begin{array}{l}\text { Deviation from European } \\
\text { rationalism and idealism. } \\
\text { Division between importers } \\
\text { and two indigenous } \\
\text { developments: progressive / } \\
\text { conservative. }\end{array}$ & $\begin{array}{l}\text { Inner strife. } \\
\text { Infection from } \\
\text { abroad: Europe, } \\
\text { a sick culture. }\end{array}$ & $\begin{array}{l}\text { Spiritual renewal of } \\
\text { national traditions. } \\
\text { Universal value of } \\
\text { Spanish recovery. }\end{array}$ \\
\hline
\end{tabular}

The author is very grateful for some critical counsels received in the reviewing process 


\section{References}

ALTAMIRA, Rafael. Psicología del pueblo español, segunda edición. [1. ed. 1902]. Barcelona: Minerva, 1917.

ARAQUISTÁIN, Luis. España en el crisol. (Un Estado que se disuelve y un pueblo que renace). Barcelona: Minerva, 1921.

ARAQUISTÁIN, Luis. El pensamiento español contemporáneo. Buenos Aires: Losada, 1962.

ÁLVAREZ JUNCO, José; FUENTE MONGE, Gregorio de la. El relato nacional: historia de la historia de España. Barcelona: Taurus, 2017.

ANKERSMIT, Frank R. Meaning, truth, and reference in historical representation. Ithaca, NY: Cornell University Press, 2012.

BERNAL, Antonio Miguel. España, proyecto inacabado: costes/beneficios del imperio. Madrid: Marcial Pons, 2005.

BUTTERFIELD, Herbert. The Whig Conception of History. London: G. Bell, 1931.

CASTRO, Américo. España en su historia: cristianos, moros y judíos. Barcelona: Crítica, 1996.

CASTRO, Américo. Sobre el nombre y el quién de los españoles. Madrid: Taurus, 2000.

COLOMER, Josep M. España: la historia de una frustración. Barcelona: Anagrama, 2018.

DARDÉ, Carlos. La idea de España en los tomos de la Historia de España dirigidos por Ramón Menéndez Pidal 1935-1980. Norba-Revista de Historia, v. 19, pp. 205-218, 2006.

DARDÉ, Carlos. La idea de España en la historiografía del siglo XX. Santander: Universidad de Cantabria, 1999.

DUQUE, Félix. L'Espagne, la nation qui n'existe pas. Revue de métaphysique et de morale, v. 81, n. 1, pp. 11-26, 2014.

FERNÁNDEZ, Juan Luis. Darwin goes to Sarajevo: Evolutionary theories underlying a century of historiography on the outbreak of the First World War. Moving the Social, no. 58, pp. 81-106, 2017.

FERNÁNDEZ, Juan Luis. Story makes history, theory makes story: Developing Rüsen's Historik in logical and semiotic directions. History and Theory, vol. 57, no. 1, pp. 75-103, March 2018.

FOX, Inman. La invención de España: nacionalismo liberal e identidad nacional. Madrid: Cátedra, 1998.

FULBROOK, Mary. Historical Theory. London: Routledge, 2008.

GARCÍA CÁRCEL, Ricardo (ed.). La construcción de las historias de España. Madrid: Marcial Pons, 2004.

GARCÍA ROVIRA, Anna María; RIQUER I PERMANYER, Borja. España, inación de naciones? Madrid: Marcial Pons, 1999.

IGGERS, Georg G. The German Conception of History: The National Tradition of Historical Thought from Herder to the Present. Middletown, CT: Wesleyan University Press, 1988.

KOSELLECK, Reinhart. The Practice of Conceptual History: Timing History, Spacing Concepts. Stanford, CA: Stanford University Press, 2001.

LAÍN ENTRALGO, Pedro. España como problema. Madrid: Seminario de Problemas Hispanoamericanos, 1949.

MADARIAGA, Salvador de. Englishmen, Frenchmen, Spaniards. London: Oxford University Press, 1928.

MADARIAGA, Salvador de. España: Ensayo de historia contemporánea. Madrid: Espasa-Calpe, 1978.

NAMIER, Lewis Bernstein. Avenues of History. London: Hamish Hamilton, 1952.

ORTEGA Y GASSET, José. Obras completas. Tomo III. Madrid: Taurus, 2012.

PÉREZ VEJO, Tomás. España imaginada: Historia de la invención de una nación. Barcelona: Galaxia Gutenberg, 2015.

PLESSNER, Helmuth. Die verspätete Nation. Frankfurt: Suhrkamp, 2001

POLYBIUS. The Histories. Cambridge, MA: Harvard University Press, 1966.

PORTER, Dale H. The Emergence of the Past: A Theory of Historical Explanation. Chicago: University of Chicago Press, 1981. 
QUIÑONERO, Juan Pedro. De la inexistencia de España: ¿quiénes son españoles? Barcelona: ED Libros, 2017.

RANKE, Leopold. Sämmtliche Werke. Band 24: Abhandlungen und Versuche. Leipzig: Duncker und Humblot, 1872 .

ROCA BAREA, María Elvira; ESPADA, Arcadi. Imperiofobia y leyenda negra: Roma, Rusia, Estados Unidos y el Imperio español. Madrid: Siruela, 2017.

RÜSEN, Jörn. Evidence and Meaning: A Theory of Historical Studies. New York: Berghahn Books, 2017.

SÁNCHEZ-ALBORNOZ, Claudio. Spain, a Historical Enigma, II. Madrid: Fundación Universitaria Española, 1975.

SÁNCHEZ-ALBORNOZ, Claudio. The Drama of the Formation of Spain and Spaniards. Madrid: Fundación Universitaria Española, 1979.
STERN, Fritz. The Varieties of History: From Voltaire to the Present. New York: Vintage Books, 1973.

THUCYDIDES. The Peloponnesian War. Translated by Steven Lattimore. Indianapolis: Hackett, 1998.

VICENS VIVES, Jaume. Aproximación a la Historia de España. Barcelona: Vicens Vives, 2003.

VICENS VIVES, Jaume. España contemporánea (18141953). Barcelona: Acantilado, 2011.

WEBER, Max. The Methodology of Social Sciences. Glencoe, IL: The Free Press, 1949.

ZAMBRANO, María. La agonía de Europa. Barcelona: Mondadori, 1988.

ZAMBRANO, María. Los intelectuales en el drama de España y escritos de la guerra civil. Madrid: Trotta, 1998.

ZAMBRANO, María. España, sueño y verdad. Barcelona: Edhasa, 2002.

ZAMBRANO, María. Escritos sobre Ortega. Madrid: Trotta, 2011. 